\title{
Egitetik haratago: pentsatzearen aribidea Gizarte Langintzan
}

\author{
Ainhoa Berasaluze \\ Gizarte Langintzako Unibertsitate Eskola / Escuela Universitaria de Trabajo Social \\ Euskal Herriko Unibertsitatea / Universidad del País Vasco \\ <ainhoa.berasaluze@ehu.es>
}

Gizarte Langintzak, oro har, gehiago erreparatu dio egiteari pentsatzeari baino. Haatik, jakintzara heldu ahal izateko, egiteaz gain pentsatzearen betebeharra ere badago. Edozein diziplina eta lanbideren garapen prozesuari eusteko, are gehiago zientzia aplikatuaz ari garenean, nahitaezkoak dira bai ezagutza praktikoak eta baita ezagutza teorikoak ere. Azken ezagutza mota hau da, hain zuzen ere, Gizarte Langintzak gorpuztu beharrekoa etorkizunari baikorki aurre egiteko. Xede hau lortzeko praxira, edo gogoeta eta ekintza bat egitera, heldu behar da, ikerketa mota zehatz baten bitartez, hots, praktika profesionalen sistematizazioaz baliatuz. Hortaz, sustatu daitekeen neurririk eraginkorrenetarikoa eremu profesionalaren eta akademikoaren arteko ituna eta elkarlana abiaraztea litzateke: jardun profesionaletik eratorritako praktika izanik ikertzekoa (zer ikertu) eta jardun akademikotik praktika hori ezagutza bihurtzekoa (nork ikertu). Artikulu honek, adierazitako tesian sakontzea eta Gizarte Langintzaren garapenean aurrera pausoak emateko erronkak mahai-gaineratzea dauka helburu.

\section{HITZ-GAKOAK:}

Gizarte Langintza, lanbidea, diziplina, ezagutza teorikoak, ezagutza praktikoak.
El trabajo social, en general, ha prestado más atención al hacer que al pensar. Sin embargo, para poder acceder al conocimiento, además de hacer se requiere pensar. Para hacer frente al proceso de desarrollo de cualquier disciplina y profesión, más aún cuando nos referimos a una ciencia aplicada, se necesitan tanto los conocimientos prácticos como los conocimientos teóricos. Este último tipo de conocimientos es, precisamente, el que tiene que fortalecer el trabajo social para afrontar el futuro con optimismo. Alcanzar esta meta supone llegar a la praxis o a la fusión reflexión-acción a través de un tipo concreto de investigación, a saber, utilizando la sistematización de la práctica profesional. Por tanto, una de las medidas más eficaces que se puede impulsar consistiría en activar la alianza y el trabajo conjunto entre el ámbito profesional y académico: investigando la práctica derivada del ejercicio profesional (qué investigar) y transformando esa práctica en conocimiento desde el ejercicio académico (quién investiga). Este artículo pretende ahondar en la tesis expuesta y plantear los retos existentes en el desarrollo del trabajo social.

\section{PALABRAS ClaVe:}

Trabajo social, profesión, disciplina, conocimientos teóricos, conocimientos prácticos. 


\section{Gogoetarako abiapuntua}

Gizarte Langintzak, oro har, gehiago erreparatu dio egiteari pentsatzeari baino, lanbideari diziplinari baino eta esku-hartzea jasotzen duten erabiltzaileei berorri baino. Aitzindari diren Mary Richmond-ek (1861-1928) eta Jane Addams-ek (1860-1935) maisutasunez uztartu zituzten esku-hartze sozial eraldatzaileak eta ezagutza zientifiko berritzaileak. Aitzitik, geroztik, Gizarte Langintzaren bilakaeran eta garapenean pragmatismoaren, enpirismoaren eta aktibismoaren planteamenduak gailendu dira; pentsamenduaren ondorio praktikoak, esperientzia eta ekintza nagusituz.

Haatik, jakin badakigu, jakitera heldu ahal izateko, egiteaz gain pentsatzearen betebeharra ere badagoela. Edozein diziplinaren eta lanbideren garapen prozesuari eusteko, nahitaezkoak dira bai ezagutza praktikoak eta baita ezagutza teorikoak ere. Azken ezagutza mota hau da, hain zuzen ere, Gizarte Langintzak gorpuztu beharrekoa etorkizunari baikortasunez aurre egiteko. Baina, zeintzuk dira Gizarte Langintzaren ezagutza teorikoak? Zein da ikerketa objektua? Nola heldu ezagutza hauetara? Nondik abiatu? Nork edo nortzuk gidatuta?

Egun, Gizarte Langintzan ezagutza teorikoak sortzeko erronkari erantzuteko baldintzak badaude, bai lanbidearen eta baita diziplinaren eremuetatik. Lanbidea finkatua dago, jarduna eta esperientzia profesionala zabala da; hortaz, ikuspuntu honetatik, badago zer ikertu. Diziplinari dagokionez, Europako Goi-mailako Hezkuntza Esparruaren bitartez, Gizarte Langintzako ikasketak gainontzeko unibertsitate ikasketekin berdintzeaz gain, irakaskuntzarako ez ezik, ikerketarako ere bideak ireki dira; beraz, badago nork ikertu.

Artikulu honetan, orain arte labur-labur adierazitako tesia modu sakon eta xeheagoan aztertuko da. Halatan, lehen zatian, Gizarte Langintzaren bilakaera historikoaren irakurketa bat egingo da, lehena eta oraina ezagutzea nahitaezkoa baita geroa eraikitzeko. Bigarren zatian, aldiz, etorkizuna izango da aztergaia, Gizarte Langintzaren erronkei aurrea hartzeko proposamenak direla medio ${ }^{1}$.

\section{Bilakaera historikoaren irakurketa: egitea}

Gizarte Langintzaren analisi historikoak etengabe eramaten gaitu lanbidera, gizarte langileen jardute profesionalera, hau izan baita Gizarte Langintzaren nolabaiteko oinarri eta zutabea. Ikuspuntu honeta-

${ }^{1}$ Lan honen lehenagoko bertsioa Gizarte Langintzako IV. Jardunaldian: 'Mendekotasunetik harantz' (Berasaluze eta Ovejas, 2011) aurkeztu eta argitaratu zen. tik, Gizarte Langintza, funtsean, lanbidean gauzatu da. Gizarte Langintzaren sorreratik, XIX. mende bukaeratik, gaurdaino lanbidea izan da ardatza, bai diziplinarako eta baita heziketarako ere. Ondorioz, Gizarte Langintzaren azterketari ekin nahi diogunean, ezinbestez, erreferentzia gisa, lanbidea aurkitzen dugu. Horregatik, Gizarte Langintzaren bilakaera aztertzerakoan edo gertaturikoa azaltzerakoan, nahitaez, lanbidearekin egiten dugu topo, gainontzeko alderdiak, izan diziplina, izan heziketa, bere mende egon baitira.

Honegatik guztiagatik, Gizarte Langintzaren azterketa historikoak, azpian eta maila sakonago batean dauden auziak begiztatzeko aukera ematen digu. Azken batean, aztergai honen sustraian Gizarte Langintza eta Gizarte Langile ereduak topa daitezke, ezagutza teorikoak eta praktikoak oinarrizko osagaiak izanik diziplinaren eta lanbidearen identitateak eraikitzeko. Hortaz, espainiar Estatuan lanbidearen eta profesionalen bilakaera historikoa aintzat hartu, eta Gizarte Langintzaren teoria-praktika binomioaren ezaugarritzearen inguruko hausnarketa egingo da.

\subsection{Esperientziako ezagutzaren printzipioa}

Historian zehar, Gizarte Langintzako lanbideak eredu desberdinak izan ditu eta gizarte langileek identitate edo nortasun profesional anitzak eraiki dituzte. Haatik, lanbide-eredu eta identitate profesional hauetan, gutxienez, aldaketarik gabeko elementu eta sinesmen bat mantendu da, esperientziazko ezagutzaren printzipioa, hain zuzen ere.

Oinarri epistemologiko honen arabera, Gizarte Langintza errealitatearekin harreman zuzena izatearen ondorioz ikasten da. Esperientziaren teorizazioari (ezagutza enpirikoari) nahiz 'jarduteko ikasi’ goiburuari bigarren mailako garrantzia esleitzen zaio; eta teoriari (ezagutza kontzeptualari) nahiz 'jarduteko azaldu' leloari leku baztertua. Teresa Zamanillok Gizarte Langintza ezagutza teorikoak duen bigarren maila hau, jardute profesionalean teoriarekiko dagoen arbuioan eta behar ezaren ustean islatzen dela adierazten du: "se sigue sosteniendo irreflexivamente que es una profesión con una base práctica que no necesita de teorías" (2008: 53).

Ezagutzara heltzeko modu honek hainbat arazo ipini ditu mahai gainean. Lehena, akats metodologikoa eta epistemologikoa litzateke, errealitatearekin harreman goiztiarra mantentzea eskatzen duelako, oraindik errealitatera era zientifikoan hurbiltzeko oinarri teoriko nahikorik ez dagoenean. Nora das Biaggiok zorroztasunez aztertzen eta gaitzesten du ezagutza lortzeko prozedura hau: “El planteo crítico se circunscribe al error metodológico y epistemológico que gira en torno a la ausencia de herramientas teóricas desde las que se construye la realidad" (1999: 96). 
Antzeman daitekeen bigarren arazoa, pragmatismoaren nagusitasuna da. Honek ez du heziketan gogoeta eraginkorrerako tarterik uzten, eta ikasleek ikasketak bukatzen dituztenean, jardutean dituzten gabeziak ez ezik, ezagutzan ere izatera bideratzen ditu; hortaz, 'ia ezer ez egiten jakitea' gertatu beharrean 'ia ezer ez jakitea' sortaraz dezake: “los alumnos que finalizan los estudios insisten en que no saben hacer casi nada. Esta queja, muchas veces repetida, ha provocado algo peor que el no saber hacer casi nada, que es el no saber casi nada" (Estruch eta Güell, 1976: 34).

Halatan, Gizarte Langintzako epistemologiak gehiago sinesten du 'egitean' 'pentsatzean' baino. Ezagutza teorikoen eta praktikoen arteko proportzionaltasun ezak, Gizarte Langintza ulertzeko modu jakin bat islatzen du: dimentsio praktikoaren garrantzia eta nagusitasuna. Honek guztiak praktikaren gainbalorazioa dakar eta beronen mitifikazioa ere ekar lezake. Nolabait, praktika mito bihurtzea, praktikak Gizarte Langintzan leku abantailatsuan ezartzea, ezagutza teorikoen gainetik baloratzea, miresgarria den estimuz inguratzea eta bikaintasuna egoztea. Azken batean, praktika mitifikatzea, jardutea Gizarte Langintzarekin berarekin parekatzea litzateke, lanbidea eta diziplina jardutearekin identifikatzea, alegia (Berasaluze, 2011).

\subsection{Lanbide ereduak Gizarte Langintzan}

Arestian aipatu dugun lez, Gizarte Langintzan eredu eta identitate ezberdinak identifika daitezke ${ }^{2}$, eta hauek oinarri, lanbide-ereduen eta identitate-profesionalen tipologia osatu³. Azal dezagun tipologia hau eta duen harremana Gizarte Langintzako ezagutza teorikoekiko zein praktikoekiko4.

\subsubsection{Laguntzarako eredua}

Lehendabiziko eredua hirurogeiko hamarkada arte garaturikoa da, Eliza Katolikoaren eta Falange Españolaren Sección Femenina delako mugimenduaren eragin ideologikoa jaso zuena (Escartín eta Suárez, 1994). Asistentzia-eredu deitu dugu, lanbidearen egitekoa baztertuak zeuden pertsonak gizartera egokitzea zelako. Bazterketaren jatorria norbanakoaren faktoreetan oinarritzen zelako ustea zegoen eta, horregatik, banakako esku-hartzea nagusitzen zen. Gizarte langileak, bereziki, emakumezkoak ziren, klase ertainekoak, askotan. Lanbidea bokazioarekin elkartzen zen, eta gizarte langileei erabiltzaileekiko inplikazio afektiboa eta pertsonala eskatzen zitzaien. Berorien bertuteak dedikazioa, besteekiko maitasuna eta berezko edo jaiotzetiko gaitasunak zein jarrerak ziren. Lanbideari planteatzen zitzaizkion erronkei eta arazo sozialei erantzuteko, emakumeen ontasuna behar zen. Beraz, garai honetan, lanbidearen hasierako hamarkadetan espainiar Estatuan, gizarte langilea bihozberatasunarekin identifikatzen zen.

Gizarte Langintzan jarduteko prestakuntza eskakizunari erreparatuz, ikasketak unibertsitatetik kanpokoak ziren, eta erdi mailako teknikari titulua eskaintzen zen, 1964an ofizialtasuna lortu zuena. Bokazioa eta izaera ziren lanbidean aritzeko ezaugarriak; ezagutzak praktikan eskuratzen zirelako ustea zegoen; sinesmen erlijiosoa lanbidearen ardatz gidaria zen, eta ezagutza teorikoak balio gutxituak gelditu ziren. Hona hemen lanbidearen eta profesionalen zereginen berri emateko, Bartzelonako Eskolak 1942-43 ikasturtean argitaraturiko liburuxkatik jasotako pasartea:

[El asistente social] es aquella persona que debe procurar que su trabajo se convierta en apostolado y que sus horas no se deslicen al compás de un sueldo, sino que lleven el empuje del sublime ideal de ganar para Dios a los que tengan bajo su labor social (Estruchek eta Güellek aipatua, 1976: 155).

\subsubsection{Eredu eraldatzailea}

Bigarren eredu eta identitatea, lehenengoak sorturiko kritika edo erreakzio modura uler daiteke. Hirurogeita hamarreko hamarkadan kokatzen da. Hego Amerikan garaturiko kontzeptualizatzearen berrikuntza-mugimenduaren eta diktadura frankistaren aurkako mugimenduaren eragin ideologikoak dira nagusi. Eredu eraldatzailea izendatu dugu, trantsizio demokratikoaren eta aldaketa soziopolitiko eta ekonomikoaren garaian gaude eta biztanleriak jasaten dituen arazoak gizarte baldintzen ondorio direla pentsatzen da. Laguntzarako esku-hartzeak alboratu, eta arazo sozialen ondorioei aurre egin beharrean, arazoen iturriei eskaintzen zaie arreta. Harreman

\footnotetext{
2 Bada ideia honekin bat egiten duen aditurik. José Vicente la identidad colectiva de los trabajadores sociales se ha transformado unida al proceso de transición democrática en España"

3 Weberren planteamendua jarraituz, tipologiak edo tipo idealak errealitatetik abiatutako abstrakzioak eraikitzeko tresna analitikoak dira, errealitatearen aspektu kualitatiboak nabarmenduz eta generalizazio lana eginez lor daitezkeenak. Hortaz, artikulu honeideal bat da, eraikitze teorikoa.

4 Jarraian azalduko diren lanbide-ereduak eta identitate-profesionalak eraikitzeko funtsezko bi osagaik eragin dute: 1) Gizarte Langintza kokatua egon den antolaketa-sistema eta garatu den gizarte-testuingurua; 2) Gizarte Langintza heziketaren bilakaera historikoa, eta beronen funtzio sozializatzailea. Luze joko liguke hori guztia zehatz-mehatz azaltzeak. Oraingoan ulertzeko lain dire zertzelada batzuk jasoko dira, baina sakondu nahi izanez gero, ondoko lan hauek kontsulta daitezke: Sarasa, 1993; Bueno, 1998; Barbero, 2002; y Brezmes, 2008.
} 
desorekatuei, gizarte gatazkei, kontzientzia hartzeari eta kolektiboki antolaturiko ekintzei buruzko ideiak nagusitzen dira. Horrela, gizarte langileek aldaketa soziala bere gain hartu, eta esku-hartze komunitarioa zabaltzen dute. Hortaz, gizarte langileek aldaketa sozialaren eragiletzat jotzen dute euren burua (Miranda, 2004). Hamarkada honetako gizarte langileak emantzipatzailea eta kritikoa izan behar du, eta konpromiso politiko zein demokratikoa eta jarrera militantea eskatzen zaizkio. Testuinguru honetan, arazo sozialen zioak azal ditzaketen ezagutzak aintzat hartzen dira, gizarte egiturarekin, estratifikazioarekin, politikarekin edo eta ekonomiarekin loturikoak, hain zuzen ere. Aurrerapausoa, beraz, aurreko hamarkadarekin erkatuz: ezagutza teorikoak, oro har, balio-gutxitzetik, arazo sozialak azaltzeko gaitasuna izaterako jauzia egiten baita.

Nolanahi ere, Gizarte Langintzari propio dagozkion ezagutza teorikoek balio gutxituak jarraituko dute. Gainera, garai honetako heziketak ez du ezagutza teorikoei eta ezagutza praktikoei ematen zaien balio ezberdina parekatzen laguntzen; izan ere, aurreko hamarkadaren ezaugarri berberak mantentzen dira: unibertsitatetik kanpoko ikasketak izatea, erdi mailako teknikari titulua lortzeko. Honek guztiak, berriz ere, Gizarte Langintzako ezagutza teorikoak alboratuak geratzea, eta ezagutza prozesuari ekiteko, errealitatearekin harreman goiztiarrean sinestea dakar. Montserrat Colomerren hurrengo aipua, bigarren eredu honen ezaugarri nagusiak laburbiltzeko baliagarria izan liteke:

El tema de la ideología del Trabajo Social y de la necesidad de un compromiso del asistente social en defensa de las clases menos favorecidas social y económicamente, surgía en todas las reuniones, debates y jornadas [en la España de los años 70] [....]. Todas las aportaciones coincidían en definir al asistente social como agente de cambio que podía influenciar en el cambio estructural y en la concienciación de la población (1990: 8-9).

\subsubsection{Eredu teknokratikoa}

Laurogeiko hamarkadatik aurrera lanbidearen eredu teknokratikoa finkatzen da. Ongizate Estatuak gizarte politiken eta gizarte zerbitzuen sorrera eta garapena dakartza. Gizarte langileak babes-sistema publiko berri honen garapenarekin inplikatzen dira: zerbitzuak sortzen, hauen funtzionamendurako arauak lantzen, eta abar (Brezmes, 2008). Zerbitzuen eta prestazioen kudeaketari eskaintzen zaio arreta gehien, eta ondorioz lanbidea burokratikoagoa da (Domenech, 1990). Esku-hartzearen aurrean, gestioaren inguruko aspektuak lehenesten dira, eta Gizarte Langintzaren aurrean gizarte zerbitzuak. Honela, gizarte langileen identitatea gizarte zerbitzuenarekin urtzen da, baliabideen kudeatzaile modura identifikatzen direlarik (Ituarte, 1990). Hau da, hain zuzen ere, gizarte langileengandik espero dena, gizarte zerbitzu publikoak egokiro administratzea.

Prestakuntzari dagokionez, aurrerapauso garrantzitsuak gertatzen dira garai honetan. 1981ean ikasketak unibertsitate mailan sailkatzen dira, eta ikasleek Gizarte Langintzan Diploma titulua eskuratzen dute. Orain arte ezagutza teorikoen eta ezagutza praktikoen artean ezagutu dugun desoreka gainditzeko pausoak ematen dira. Aurreko ereduetan ez bezala, eredu honetan ezagutza teorikoak beharrezkoak dira. Baina ez kontzeptualak edo abstraktuak, instrumentalak (berehalako erabilpena izango duten ezagutza aplikatuak), eta prozedurari loturikoak (jarduna erregulatzen duen arau multzoa) baizik: komunikazioan trebatzeko baliabideak, protokoloak, harremanak lantzeko teknikak, araudia, tresna administratiboak, eta abar (Giménez, 2006). Horrela bada, ezagutza teorikoak lanbidearen instrumentaltzat hartzen dira, batez ere aspektu teknikoei lotuak daudenean balioesten direlarik. Jarraian, garai honetan gizarte langileen zeregina egokiro deskribatzen duen aipamena ekarri dugu:

\section{El asistente social debe saber cómo tratar a un anciano, a un disminuido, enfrentarse a un pro- blema de gitanos [...]. Debe saber también cómo tramitar cualquier acción administrativa, una pensión, una ayuda, una solicitud, cómo dirigirse aquí y allá en cada caso ... Pues sí, debe saber todo eso y lo decimos en serio. Creer en la ASP [atención social primaria] de verdad, no porque ahora esté de moda, quiere decir creer en todo eso [...]. Creer en la atención primaria quiere decir impulsar y exigir toda una estructura que le dé soporte (Casals-Montse, 1987: 117-118).}

\subsubsection{Eredu praxiologikoa}

Laugarren tokian, etorkizuneko eredua izan daitekeena kokatu da. Egun dauden aztarnetan oinarriturik, etorkizuneko aukeren esplorazioaren ondorioz lorturiko eredua litzateke, prospekzio modura. Hori dela eta, hasi berri dagoen eta, beraz, eremuko diskurtsoetan oraindik denborak kristaldu gabeko lanbideeredua eta identitate-profesionala aurki daitezke. Beronetan, harreman-lana dugu gizarte langilearen baliabide nagusia eta erabiltzaileekin garatzen duen lotura-harremana lanbidearen berezko tresna indartzailea. Josep Manuel Barberoren (2002) hitzetan, Gizarte Langintzak gizartea harreman-sistema gisa ulertu behar du, harremanetan eta harremanen berreraikuntzan esku hartuz ${ }^{5}$. Etorkizuneko eredu

5 Beste aditu batzuk laguntza-harremana (Pérez eta Bueno, 2007; Brezmes, 2008) edo gizarte-lotura (Robertis, 2000) kontzeptuak erabili dituzte Gizarte Langintza esku-hartzearen ardatza adierazteko. 
hau eredu praxiologikoa izendatu dugu, jardute profesionalak ezagutza teorikoak dituelako erreferentzia puntu, teoriaren eta praktikaren arteko batasuna hautsezina bihurtzen duelako.

Gizarte langilea profesionalarekin ${ }^{6}$ identifikatzen da, esku-hartze sistematizatua eta eskualdagarria burutzen duena, ezagutza teorikoak lanbidearen tresna garrantzitsuen artean kokatzen dituena. Gizarte Langintza heziketak unibertsitate mailakoa izaten jarraitzen du, baina Gizarte Langintzako Gradua goi-mailako titulazio bilakatzen da. Eredu honek ezagutza instrumentalak ez ezik, kontzeptualak (Gizarte Langintzaren teoria eta ereduak) ere lanbidearen ardatzekotzat ditu. Zientifikotzat onartutako ezagutza teorikoen jakintza eta jabetza daude eredu honen oinarrian (Viscarret, 2009).

Praxis, por ser integración del saber teórico y de la práctica, es también ese recorrido de ida y vuelta que debe existir entre las fuentes del saber y los profesionales ejercientes (Barriga, 2009: 41-43).

Ikus dezagun, taula batera ekarrita, Gizarte Langintza lanbidearen eta profesionalen bilakaera historikoan ezagutzei loturiko ezaugarri nagusiak. Lanbidearen bilakaera historikoan oinarrituz, eta hamarkada ezberdinetan nagusitu diren ereduak eta identitateak azaldu baditugu ere, errealitatea edozein eraikuntza teorikoa baino askoz ere konplexuagoa dela esan beharra dago. Izan ere, lehengo denboretako hiru ereduek eta identitateek egun, neurri batean, indarrean jarraitzen dutela esan genezake. Gizarte Langintza ikasten dauden ikasleen diskurtsoei erreparatu ezkero, maiz eredu eraldatzailea aurkitzen dugu. Beste horrenbeste gertatzen da gizarte langileen diskurtsoekin, laguntza eredua eta teknokratikoa sarri ageri dira. Eredu praxiologikoa litzateke batzuen zein besteen diskurtsoetan ahulena. Honez gain, eredu eta identitate ezberdinak ezaugarritzen dituzten elementuak, eragile eta diskurtso beraren baitan aurkitzerik ere badago.

\section{Etorkizunaren garapenerako erronka: pentsatzea}

Esan bezala, orain arte Gizarte Langintza ulertzeko eta bere zereginak zehazteko hiru modu diferente ezagutu ditugu, eta guztietan praktikak edo jardunak izan du lehentasuna, ezagutza teorikoak mendeko egonik. Gizarte Langintzaren ezagutza teorikoak ez daude praktikarekin loturik. Teoriak azken helburuak elikatzen ditu, baina ez da erabili praktika edo lanbidea elikatzeko. Lanbidea, erreferentzia praktikoekin ezagutza teorikoekin baino gehiago identifikatu da. Bada, hausnarketa epistemologikoari gutxi erreparatu zaio, eta pragmatismoa, enpirismoa zein aktibismoa gailendu direla esan genezake.

Laugarren prospekzio-eredua litzateke Gizarte Langintzako ezagutza teorikoak aintzat hartzen eta balioesten dituena. Eredu honen helburua praxira heltzea da, gogoetak eta ekintzak bat egitea, teoriaren eta praktikaren artean eragin-trukatzea eta berrelikatzea; hau da, praktika zehatzak planteamendu teoriko orokor baten baitan txertaturik ulertzea. Baina oraindik hazi-minetan dago, eredu izateko bideari heldu nahian dabil; eta horregatik, eredu honen aztarna ahulak besterik ez da begiztatzen.

1. Taula. Gizarte Langintzako lanbidea eta bere harremanak ezagutzekin

\begin{tabular}{|c|c|c|c|c|}
\hline & 6oko hamarkada arte & 70eko hamarkada & $\begin{array}{l}\text { 8oko hamarkadatik } \\
\text { gaurdaino }\end{array}$ & Etorkizunekoa \\
\hline Lanbide eredua & Laguntzailea & Eraldatzailea & Teknokratikoa & Praxiologikoa \\
\hline Identitate profesionala & Bihozbera & Eragilea & Kudeatzailea & Profesionala \\
\hline Heziketa & $\begin{array}{l}\text { Unibertsitatetik } \\
\text { kanpokoa: erdi mailako } \\
\text { teknikaria }\end{array}$ & $\begin{array}{l}\text { Unibertsitatetik } \\
\text { kanpokoa: erdi mailako } \\
\text { teknikaria }\end{array}$ & $\begin{array}{l}\text { Unibertsitatekoa: } \\
\text { diploma titulua }\end{array}$ & $\begin{array}{l}\text { Unibertsitatekoa: } \\
\text { gradu titulua }\end{array}$ \\
\hline $\begin{array}{l}\text { Ezagutza teorikoak eta } \\
\text { ezagutza praktikoak }\end{array}$ & $\begin{array}{l}\text { - Sinesmen erlijiosoak } \\
\text { ardatz. } \\
\text { - Esperientziazko } \\
\text { ezagutzaren printzipioa. } \\
\text { - Ezagutza teorikoak } \\
\text { balio gutxituak. }\end{array}$ & $\begin{array}{l}\text { - Konpromiso politikoa } \\
\text { ardatz. } \\
\text { - Esperientziazko } \\
\text { ezagutzaren printzipioa. } \\
\text { - Berezko ezagutza } \\
\text { teorikoak } \\
\text { baliogutxituak. }\end{array}$ & \begin{tabular}{|l|} 
Ezagutza \\
instrumentalen \\
eta prozedurazkoen \\
balioztapena. \\
- Esperientziazko \\
ezagutzaren printzipioa.
\end{tabular} & $\begin{array}{l}\text { - Ezagutza } \\
\text { instrumentalen, } \\
\text { prozedurazkoen eta } \\
\text { kontzeptualen } \\
\text { balioztapena. } \\
\text { - Ezagutza teorikoak eta } \\
\text { praktikoak oinarri }\end{array}$ \\
\hline
\end{tabular}

Iturria: Egileak landua.

\footnotetext{
6 Profesionala eta teknikaria terminoen arteko aldea esplizitu adieraztea komeni da. Luís A. Barrigaren (2009) azalpenei jarraiki, profesionala egoera anitzak ulertzeko gaitasuna duen pertsona da, besteek begiratu dutena begiratzeko eta gauza gehiago ikusteko gai dena; konplexutasunean espezialista eta aurrez zehaztu gabeko errealitateetan esku-hartzen duena. Teknikaria aldiz, tekniketan aditua da, eta aurrez zehazturiko errealitateetan esku-hartzeko aplikagarriak diren irtenbideak dituena.
} 
Azken eredu honen garapenak, Gizarte Langintzako lanbidetik diziplinara jauzi egitera behartzen gaitu; lanbidean ez ezik diziplinan ere fokua jartzera. Diziplina eta lanbidea, teoria eta praktika, binomio hauen arteko hartu-emanaren analisiak eremu epistemologikoan kokatzen gaitu. Halatan, Gizarte Langintzan ezagutzen eta esku-hartzeen arteko harremanen inguruko gogoeta egitea da artikulu honek izan nahi duen azken parada.

Egun, teoriaren eta praktikaren arteko eztabaida, zahar bezain antzua da. Eremu zientifikoan aurrez aurreko hau gainditua dago. Teoria eta praktika uztarri berean doaz, bata eta bestea ezin askatuzko moduan daude elkarri lotuak, bata bestean txertatua (Beltran, 2002).

Aitzitik, Gizarte Langintzan ezagutza teorikoen eta ezagutza praktikoen arteko harremana arazotsua dela agerikoa da, uztardura arazo klasikoa izan dela, alegia (Zamanillo, 1992; Viscarret, 2009). Ezagutza praktikoak, Gizarte Langintzaren identitate-ardatz bihurtu dira. Eta bilakaera historikoaren azterketak irakatsi digu, ordea, hor dagoela Gizarte Langintzaren gabezia eta herrenik larriena:

[...] esta lógica binaria que escinde el pensar y el hacer, el conocer y el actuar, ha tenido en el caso del Trabajo Social costos muy altos. Implícitamente subyace la idea de que poner el esfuerzo en la práctica investigativa es de algún modo un no compromiso con los principios del Trabajo Social, fuertemente ligados a la intervención con los sectores más desfavorecidos (Banda, 2009: 48).

Hausnarketa honetan, Gizarte Langintza eremutik, bai lanbidetik eta baita diziplinatik ere, ezagutza teorikoei behar baino gutxiago erreparatu zaiela, edo ezagutza praktikoetan arreta osoa jarri dela, mahai gaineratu dugu. Baieztapen hau kritika suntsitzailetzat jo daiteke eremu barruko eragileen aldetik. Arrotza ere suerta daiteke, 'barrukoa' identifika daitekeen pertsona batengandik datorrela kontuan izanik. 'Kanpoko'-engandik etorri izan balitz ez zatekeen inor harrituko, Gizarte Langintzari dioten mesprezu eta balio falta justifikatuko lukeelako, ezjakintasunaren ondorio. Baina barrutik datorrenean ulergaitzago bilakatzen da, behintzat azaleko irakurketa batean oinarrituriko iritzia bada. Sakontasun handiagoz irakurri ezkero, aurreiritziak mugatuz eta autokritika jarrerari eutsiz, xede baikorragoa duela ohar gaitezke: garapenaren eta errekonozimendu sozialaren etorkizunera begira jarriko duena, hain zuzen ere.

Esanak esan, jakina da Gizarte Langintzaren urteetako dinamikari ezin zaiola goizetik gauera buelta eman. Baina jakin ere badakigu, hau ezin dela aitzakia izan Gizarte Langintzak ezarian-ezarian egin behar duen bideari uko egiteko. Soilik Gizarte Langintzako ezagutza teorikoen eta praktikoen batasu- nak, ibilbide bateratuak, eraman dezake Gizarte Langintza bere osotasunean garatzera eta behar duen errekonozimendua lortzera (Lera, 2008). Eremuko eragileok Gizarte Langintzak ezagutzarekin duen harremanari buruz gogoeta egin beharko dugu, eta gradu titulu berriak eman ditzakeen aukerak egokiro erabili etorkizuna eraikitzeko (Gómez, 2010). Une erabakigarria, beraz, Gizarte Langintzaren eta eragileen identitatea teoriaz ere gorpuzteko. Erronka honi aurre egiteko, eta abiapuntu modura, jardute profesionalean eta akademikoan ezagutzei loturiko hainbat alderdi argitzeari eta zenbait neurri hartzeari komenigarria deritzogu.

\subsection{Lanbide jarduna}

Lanbidearen ikuspegitik, etorkizuneko erronka nagusia ezagutzak transferitzea litzateke. Egun, gizarte langileek zorroztasunez esku-hartzen dute, izan ere, jardun profesionalak izugarrizko garapena izan du. Baina jardun profesional horretatik eratorritako ezagutza praktikoak ez dira eskualdatzen, profesional bakoitzarengan gelditzen dira. Zentzu honetan ahaleginak egin behar dira, lanbidean ikasitakoa ezagutza bihurtu behar da, bi helbururekin: a) ezagutza horiek besteentzat erabilgarriak izan daitezen eta $b$ ) gizarte langileek egiten dutena ikusgai egon dadin. Hau lortzeko, hainbat neurri hartu beharko lirateke. Laburlabur aipatuko ditugu garrantzitsuenak.

Lehenik, gizarte langileek ezagutza teorikoak aintzakotzat edukitzea, aplikatzea eta duten balioa ematea. Jardute profesionala praktika bat da, baina horrek ez du esan nahi aktibismo kaotikoa edo orientabide gabekoa izan behar denik. Kontua ez da ekintza ekintzagatik; ekintza teoriaren praktika bat $\mathrm{da}$, eta zentzu horretan ekintza guztien baitan teoriak daude. Finean, jardute profesionala, teoriaren eta praktikaren arteko sintesia da. Ezagutza teorikoa esku-hartze profesionalen zorroztasunerako eta zehaztasunerako elementu muina da. Lanbidea Gizarte Langintzako teorian eusten da, esku-hartze profesionalak teoriaren ekarpenak ditu euskarri (Howe, 1999; Miranda, 2004; Zamanillo, 2008). Gizarte langileek errealitatean esku-hartzeko eta eraldaketak lortzeko behar duten halabeharreko tresna, Gizarte Langintzak dituen eta sortzen dagoen ezagutza teorien ezagupena da.

Bigarrenik, lanbidea Gizarte Langintza akademiatik buruturiko ikerketetan oinarritzea. Ikerketa errealitatea ezagutzeko modu bat da; berehala hitz egingo dugu honetaz. Baina, gizarte langileen kasuan, beharrezkoak dituzten ezagutzak eskuratzeko biderik samurrena, besteek (Gizarte Langintza akademiak, esaterako) buruturiko ikerketetan oinarritzea litzateke. Nolabait, lanbidearen ikuspuntutik, 'ezagutza teorikoen jabe izatea' eta 'ikerketen egile zuzena izatea' ezin ditugula sinonimotzat hartu, eta Gizarte Langintzaren jardute profesionalean, ezagutza teorikoa ezinbestekoa dela planteatu nahi da. 
Esplikazio-ildo honetatik jarraituz, jardute profesionalaren zeregin nagusia errealitatea eraldatzeko eta gizarte ongizatea sustatzeko esku-hartzea burutzea dela esan genezake, eta ez ikerketa, edo ez maila berean behintzat. Egia da, jardute profesionala ezagutza zientifikoak sortzeko funtsezko iturri bilakatzen dela, baina ez ditu automatikoki produzitzen.

Jardunetik ezagutzak sortzeko ikerketa dugu beharrezko, metodo zientifikoan oinarrituriko praktika. Honek esan nahi du, gizarte langileak jarduteaz gain, bigarren ekintza bat ere egin dezakeela: ikerketa. Baina ez jardutearekin ikertzen dagoela. Bat gatoz, lanbidetik ikerketa burutzea interes handikoa dela defendatzen dutenekin (Red, 1993; Brezmes, 2008), baina jardute profesionalean dabiltzan gizarte langileak ezin ditugu ikerlari bihurtu; ikerketa ez da profesionalen eginkizun nagusia, eta ezin zaie beronen erantzukizuna leporatu.

Hirugarrenik, eta lanbidearen eta ikerketaren eremuen uztarduran arreta jartzekotan, esku-hartze profesionalen sistematizaziotik eratorritako produkzio zientifikoa azpimarratu beharko genuke, Susana Garcíak (1998) ikerketa enpirikoa deitu duena. Gizarte Langintzako Elkargo Ofizialen Kontseilu Orokorreko lehendakaria den Ana Isabel Limak (2010) ere, berriki, gizarte langileek egiten dutena eta dituzten gaitasunak ikusgai egoteko, praktika profesionalaren sistematizazioan sakondu beharra dagoela adierazi du.

Esku-hartzeak sistematizatzeak, planteamendu teoriko orokorren markoan diseinaturiko lan-hipotesiak egiaztatzea ahalbidetzen du. Adibidez, familiekin aurrera eramandako Gizarte Langintza esperientzien sistematizazioak. Esperientzia hauek planteamendu teoriko sistemikoen itzalpean gauzatzen badira, teoria sistemikoaren premisen baliotasuna baieztatzeko Gizarte Langintzarentzat lagungarria izan litezke. Haatik, esperientzien sistematizazio prozesuak, arestian azalduriko marko teoriko baten baitan egindako kontraste enpirikoa helburu ez badute, ezagutza zientifikoak sortu beharrean, esperientzien deskripzio hutsak bilakatzeko arriskua legoke, ezagutza enpirikoen mailara heldu ezinik (Giménez, 2006).

Hartara, nahiz eta Gizarte Langintzako literaturan, esku-hartze profesionalaren sistematizazioaren aldeko ikuspegia babestu, gauzatzerakoan berorren zailtasuna agerikoa da (Sheldon, 1978). Horregatik, lanbidearen erronka honi aurre egiteko, eremu akademikoarekiko elkarlana ezinbestekoa da.

\subsection{Akademia jarduna}

Diziplinaren ikuspegitik, Gizarte Langintzan eta Gizarte Langintzarako ikerketak burutzea litzateke erronka. Gizarte Langintzaren eremu akademikoa, historikoki, oso ahula izan da. Gizarte Langintzako lehenengo Eskola, Bartzelonan 1932an sortu zenetik gaur arte, unibertsitate mailara heldu da. Baina uni- bertsitate barnean, mailarik baxuenean kokaturik egon da, diplomaturan, hain zuzen ere. Honek, diziplinaren garapena guztiz baldintzatu du. Akademian jardun dutenak, funtsean, irakaskuntzara mugatu behar izan dira, oztopo nabarmenak izan dituztelarik ikerketan murgiltzeko. Egun, berriki bada ere, gainontzeko diziplinek duten mailara heldu da, dagoeneko gradua, masterrak eta doktoregoak ezarriak daude. Horrenbestez, Gizarte Langintza jakintzaarloan ezagutzak sortzeko baldintzak izanik, ahaleginak egiteko garaia da, bi helburuokin: a) Gizarte Langintza ezagutza teorikoz ere gorpuztea eta b) diziplina garatzea.

Helburu hauek lortzeko ikerketa dugu beharrezko. Gizarte Langintza akademiaren zeregin nagusia, heziketarekin batera, ikerketa da. Diziplinak Gizarte Langintzak berezko duen ezagutza objektuari eta esku-hartze objektuari buruzko ezagutza berriak sortu behar ditu.

Betekizun nagusi honek, lanbidean alderantziz gertatzen den bezalaxe7, ez du esku-hartzetik kanporatzen (hausnarketa-ekintza edo ikerketa-ekintza parte-hartzailea dugu honen adibide paradigmatikoa), baina bai esku-hartzea diziplinaren funtzio zerrendaren bigarren mailan kokatu. Horregatik, Gizarte Langintzan ikerketa eta, ondorioz, ezagutzak eskasak direla esaten denean, gehiago zehaztu beharko genuke, azken finean, erantzukizuna Gizarte Langintzaren alderdi bati, akademiari, egotzi beharko geniokeelako.

Jardute akademikoan beraz, irakasle-ikerlariek ezagutza berriak sortzea eta burutzen dituzten ikerketetan praktika aintzakotzat edukitzea eta balioestea litzateke erronka. Izan ere, Gizarte Langintzako ikerketetan praktika izan daiteke aztergaia, edo eskuhartze prozesua ikerketa objektu. Kontua ez da teoria teoriagatik, ordea, teoria beharrekoa da praktika ulertzeko, eta berau orientatzeko. Horregatik, akademiatik ikerketak burutzerakoan eremu profesionala aintzakotzat hartu beharko da.

\section{Jakintza helmuga}

Gizarte Langintza zientzia aplikatua da, ekintzara bideratua dagoena. Teoria eta praktika, diziplina eta lanbidea, ikerketa eta esku-hartzea, Gizarte Langintzaren beraren bi alderdi dira, elkarren beharra

\footnotetext{
7 Garvin-ek eta Tropman-ek (1992) Gizarte Langintzako diziplinaren eta lanbidearen arteko ezberdintasunak antzeman daitezen, eginkizunak aurrez aurre jartzen dituzte. Hortaz, euren aburuz, gizarte langileek 'egiten' duten bitartean, akademikoek 'hausnartzen' dute; gizarte langileek 'errealitatea eraldatu' nahi duten bitartean, akademikoek 'errealitatea ulertu' nahi dute; gizarte langileei errealitate sozialean 'inplikatzea' eskatzen zaien bitartean, akademikoei ‘urruntzea' eskatzen zaie; gizarte langileek arazo sozialei aurrea hartzeko tresnak behar dituzten bitartean, akademikoek arazo sozialak ulertzeko elementuak behar dituzte.
} 
dutenak, bata bestean txertatua dagoena. Honek iradokitzen du, bi espazioen arteko jarrera osatua eta bateratua sustatu beharra dagoela Gizarte Langintzaren garapena ahalbidetzeko.

Halaber, Gizarte Langintzaren bi alderdiek ondo berezituak egotea beharko lukete ere. Ezagutza subjektuak eta esku-hartze subjektuak, hainbat helburu partekatzen dituzte, maiz gauza berak egiten dituzte, oso bestelakoak diren arren. Hainbat elementu komunean izanik ere, argi desberdin daitezkeen praktikak ditugu. Bata, jardute akademikoa, Gizarte Langintzaren inguruan ezagutza zientifikoen produkzioan lan egitean datza. Bestea, jardute profesionala, errealitate sozialaren eremuan esku-hartzea eta eraldaketak sustatzea dauzka helburu.

Honaino iritsita, jardute profesionalari ezagutzaz baliatzea eskatu behar baldin bazaio ere, ezin zaio atxiki Gizarte Langintzako ezagutza teorikoen produkzioa, ez baita bere egiteko nagusia. Lanbidetik ikerketak egin daitezke edo ikerketetan parte har daiteke, baina Gizarte Langintzaren ekintza teorikoaren ardura eta ikerketarena eremu akademikoari galdatu behar zaizkio, bere funtsezko zereginen artean dauden heinean. Eremu profesionalak, eguneratua egon dadin ideiak, ezagutzak eta planteamendu epistemologiko berritzaileak behar ditu. Eremu akademikoak, aldiz, errealitatera egokitzeko berarekin harreman zuzenean egon behar du.

Horregatik, diziplinak ezagutza teorikoak sortzean eta lanbidearekin lankide gisa aritzean, eta lanbideak esku-hartzeak burutzean eta diziplinarekin elkarlanean aritzean, legoke gakoa edo Gizarte Langintzak dituen erronkei aurrea hartzeko abiapuntua. Nolabait, bakoitzari (lanbideari eta diziplinari) bere ekarpena aitortu, hierarkizazioak gainditu eta elkarren arteko uztarduratik jakintza gorpuztu. Gizarte Langintzaren garapenean aurrera pausoak emateak, bestelako gizarte zientziekin diziplinen arteko moduan aritzeko askatasuna eta gaitasuna emango dio. Hau da hurrengo hamarkadetan jorratu beharreko ardatza.

Gure historia hiru garaitan kontatua izan liteke: gure jatorrian, egitea; gero, egiten duguna pentsatzea; egun, pentsatzen duguna jakin nahi dugu.

Nora Aquín 


\section{Bibliografía}

BANDA, T. (2009): "El nacimiento de una nueva profesión: el Trabajo Social”, FERNÁNDEZ, T. (koord.): Fundamentos del Trabajo Social, Madril, Alianza, 15-108 or.

BARBERO, J. M. (2002): El Trabajo Social en España, Zaragoza, Mira.

BARRIGA, L. A. (2009): “El sexto sentido en Trabajo Social”, in: XI Congreso de Diplomados/as en Trabajo Social y Asistentes Sociales de España: 'Trabajo social, sentido y sensibilidad' [aktak], Zaragoza [rhttp://www.cgtrabajosocial.es/alicante/documentos/congreso/39_Luis_Barriga.pdf> helbidean eskuragarria].

BELTRÁN, M. (2002): "Cinco vías de acceso a la realidad social”, in GARCÍA, M.; IBAÑEZ, J.; eta ALVIRA, F. (bil.): El análisis de la realidad social. Métodos y técnicas de investigación, Madril, Alianza, $15-55$ or.

BERASALUZE, A. (2011): Practicumaren eragina Gizarte Langintzako Heziketan: Gasteizko Eskolaren Kasua 1964-2009, Bilbo, Euskal Herriko Unibertsitateko Argitalpen Zerbitzua.

BERASALUZE, A.; eta OVEJAS, M. R. (2011) [koord.]: Gizarte Langintzako IV. Jardunaldia: 'Mendekotasunetik harantz' / IV Jornada de Trabajo Social: 'Más allá de la dependencia' [aktak], Bilbo, Euskal Herriko Unibertsitateko Argitalpen Zerbitzua.

BREZMES, M. (2008): El Trabajo Social en España, una profesión para la democracia, Murtzia, Murtziako Unibertsitatea.

BUENO, J. R. (1998): La construcción y transmisión de los saberes en Trabajo Social, Valentzia, Valentziako Unibertsitatea.; Barbero, 2002; Brezmes, 2008.
CASALS-MONTSE, I. (1987): "Radiografía a la atención social primaria”, Documentación Social, 64. zenb., 115-123 or.

COLOMER, M. (1990): “Trabajo social en España en la década de los 70", Servicios Sociales y Política Social, 20. zenb., 6-12 or.

DAS BIAGGIO, N. (1999): “Propuesta de formación de trabajadores sociales desde una perspectiva de género", Servicios Sociales y Política Social, 45. zenb., 85-97 or.

DE LA RED, N. (1993): Aproximaciones al trabajo social, Madril, Gizarte Langileen Elkargo Ofizialen Kontseilu Orokorra; Siglo XXI.

DE ROBERTIS, C. (2000): “Respondiendo a las nuevas situaciones desde los fundamentos del trabajo social”, in: IX Congreso de Diplomados/as en Trabajo Social y Asistentes Sociales de España: 'Trabajo Social, compromiso y equilibrio' [aktak], Santiago Compostelakoa.

DOMENECH, R. (1990): "La evolución del trabajo social en España en la década de los años ochenta", Servicios Sociales y Política Social, 20. zenb., 14-18 or.

ESCARTíN, M. J.; eta SUÁREZ, E. (1994): Introducción al trabajo social. I. Historia y fundamentos teóricoprácticos, Alacant, Amalgama.

ESTRUCH, J.; eta GÜELL, A. M. (1976): Sociología de una profesión, los asistentes sociales, Bartzelona, Península.

GARCÍA, S. (1998): Especificidad y rol en trabajo social, Buenos Aires, Lumen-Humanitas.

GARVIN, C. D.; eta TROPMAN, J. E. (1992): Social Work in Contemporary Society, Englewood-Cliffs, Prentice Hall. 
GIMÉNEZ BERTOMEU, V. V. (2006): “El desempeño profesional de los/as trabajadores/as sociales y sus relaciones con el contexto laboral" [doktorego tesia], Alacant, Alacanteko Unibertsitatea.

GÓMEZ GARCíA, R. (2010): "Variables en la profesionalización del trabajo social”, Zerbitzuan, 48. zenb., 87-95 or. [<http://www.zerbitzuan.net/documentos/zerbitzuan/Variables\%20en\%2ola\%2 oprofesionalizacion.pdf $>$ helbidean eskuragarria].

HOWE, D. (1999): Dando sentido a la práctica: una introducción a la teoría del trabajo social, Granada, Maristán.

ITUARTE, A. (1990): "Trabajo Social y Servicios Sociales: aportes para una clarificación necesaria", Documentación Social, 79. zenb., 49-63 or.

LERA, C. I. (2008): “La práctica de investigación en el campo disciplinar de trabajo social", Acciones e Investigaciones Sociales, 26. zenb., 207-222 or.

LIMA, A. I. (2010): "Nuevas oportunidades del trabajo social”, Servicios Sociales y Política Social, 89. zenb., 9-27 or.
MIRANDA, M. (2004): De la caridad a la ciencia. Pragmatismo, interaccionismo simbólico y trabajo social, Zaragoza, Mira.

PÉREZ COSÍN, J. V.; eta BUENO, J. R. (2007): “El trabajo social profesional en España", in: DESLAURIERS, J.-P.; eta HURTUBISE, Y. (zuz.): El trabajo social internacional. Elementos de comparación, Buenos Aires, Lumen-Humanitas.

SARASA, S. (1993): El servicio de lo social, Madril, Imserso.

SHELDON, B. (1978): "Theory and practice in Social Work: A re-examination of a tenuous relationship", British Journal of Social Work, 8, 1-22.

VISCARRET, J. J. (2009): Modelos y métodos de intervención en Trabajo Social, Madril, Alianza.

ZAMANILLO, M. T. (2008): Trabajo social con grupos y pedagogía ciudadana, Madril, Síntesis.

- (1992): “La intervención profesional”, in: VII Congreso de Diplomados/as en Trabajo Social y Asistentes Sociales de España: 'La intervención profesional en la Europa sin fronteras' [aktak], Bartzelona. 